\title{
SIMBAS: Sistem Informasi Bantuan Jasa Pandemi Covid-19
}

\author{
Rizky Andrian, Ignatius Dimas Priambodo, Nadia Azka Huda Prastiwi, Dewangga Ardian Pratama, Hanavi, Nurmajid \\ Setyasaputra, Dahlia Winingsih \\ Sekolah Teknik Elektro dan Informatika \\ Institut Teknologi Bandung \\ Bandung, Indonesia \\ rizky.andrian@s.itb.ac.id, ignatius.dimas@s.itb.ac.id, nadiaazkahp@s.itb.ac.id, \\ dewangga@s.itb.ac.id, hanavi@s.itb.ac.id,nurmajid.setyasaputra@s.itb.ac.id, \\ dahlia.winingsih@s.itb.ac.id
}

\begin{abstract}
Abstrak-Merebaknya kasus covid-19 di Indonesia mengakibatkan munculnya berbagai permasalahan, tidak hanya berdampak pada sektor kesehatan tetapi juga sektor sosial ekonomi. Dalam dunia kesehatan, peningkatan jumlah pasien yang semakin banyak membuat sejumlah fasilitas kesehatan yang ditunjuk mengalami kekurangan tenaga dalam melakukan tugasnya. Hal ini mendorong pemerintah dan lembaga yang ditunjuk dalam penanganan covid-19 membuka pendaftaran relawan baik medis maupun non medis untuk mempercepat penanganannya. Selain penanganan kasus positif, langkah-langkah pencegahan juga menjadi fokus utama dalam menekan penyebaran dan peningkatan kasus covid-19. Beberapa langkah pencegahan diantaranya adalah penggunaan masker, mencuci tangan menggunakan sabun atau hand sanitizer, pembatasan interaksi langsung dan sterilisasi ruang publik seperti rumah ibadah, sekolah, dan tempat pelayanan umum lainnya. Namun, saat ini produk-produk yang berkaitan dengan tindakan pencegahan menjadi langka dan bernilai tinggi sehingga banyak masyarakat yang tidak dapat memperolehnya. Dalam mengatasi permasalahan ini, dibutuhkan bantuan berupa jasa maupun produk yang dapat digunakan untuk melakukan tindakan pencegahan. Kondisi ini kemudian mendorong berbagai lapisan masyarakat baik secara individu maupun organisasi untuk turut membantu dalam pencegahan dan penanganan covid19. Di sisi lain, banyaknya permintaan yang diajukan membuat calon pemberi jasa kesulitan dalam menentukan penerima bantuan yang benar-benar membutuhkan. Untuk itu, dalam penelitian ini diusulkan suatu sistem informasi yang dapat mempertemukan calon pemberi jasa dengan calon penerima bantuan yang berhak. Sistem ini diharapkan dapat mempercepat proses perekrutan relawan untuk penanganan kasus covid-19 dan penyaluran bantuan jasa yang dibutuhkan dalam pencegahannya.
\end{abstract}

Keywords—-sistem informasi, bantuan jasa, coronavirus disease (covid-19)

\section{PENDAHULUAN}

Coronavirus disease (covid-19) merupakan penyakit yang disebabkan oleh jenis baru virus corona yang dapat menyebabkan gangguan pernapasan ringan hingga berat bagi manusia yang saat ini belum dapat ditemukan vaksinnya. Di Indonesia status tanggap darurat covid-19 telah ditetapkan sejak 29 Februari 2020, namun sebagaimana laporan yang dikeluarkan oleh gugus tugas covid-19 penyebaran kasus positif semakin meningkat dan meluas. Tercatat per tanggal 1 Mei 2020 terdapat 10.551 kasus positif, 1.591 pasien sembuh dan 800 orang meninggal dunia yang tersebar di 297 kabupaten pada 34 provinsi di Indonesia [1]. Kondisi ini kemudian menimbulkan berbagai permasalahan yang harus dihadapi diantaranya kurangnya tenaga medis dan logistik yang diperlukan fasilitas kesehatan yang ditunjuk dan lembaga penanganan covid-19, perlunya tindakan pencegahan di berbagai wilayah serta dampak sosial ekonomi yang ditimbulkannya. 


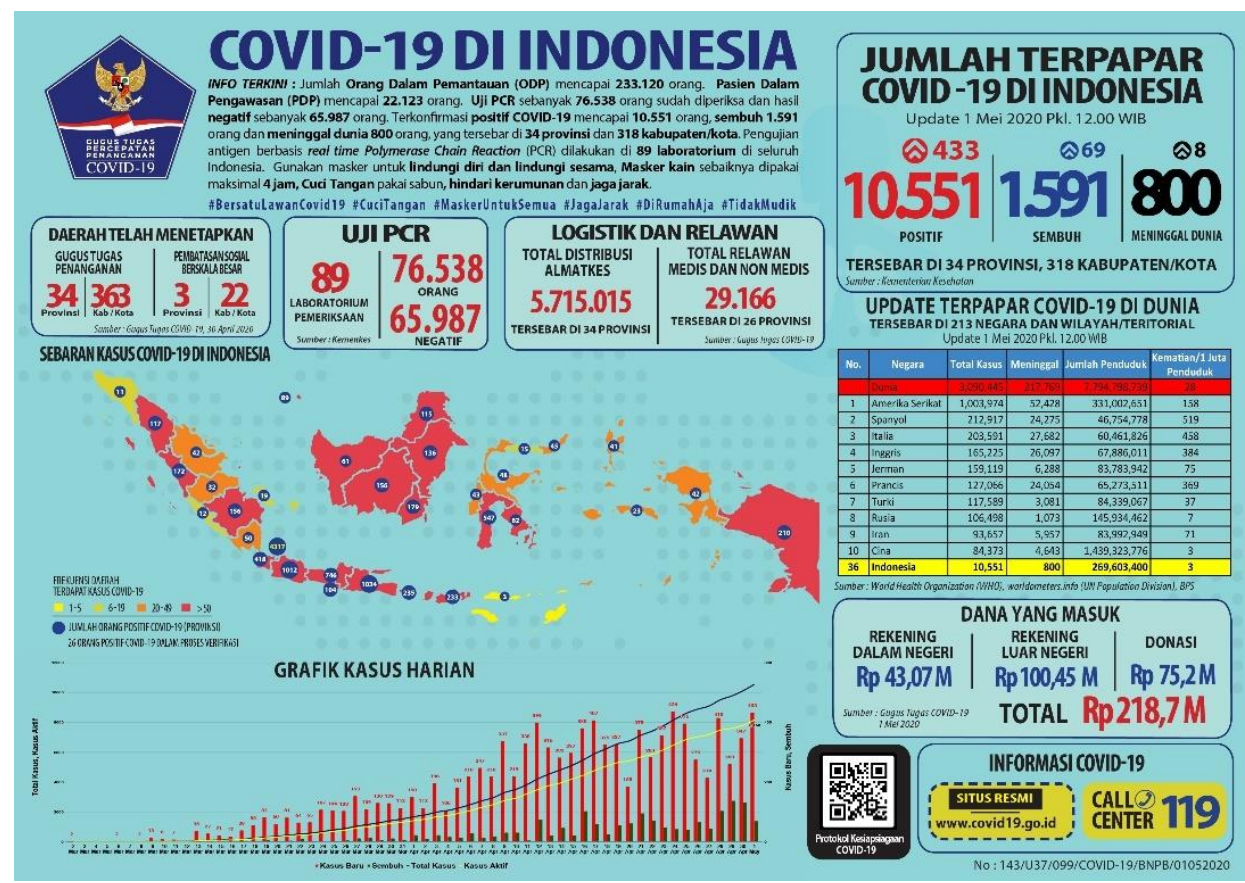

Gambar 1. Infografis sebaran kasus covid-19 di Indonesia per tanggal 1 Mei 2020 [1]

Diantara langkah pencegahan covid-19 yang disarankan oleh World Health Organization (WHO) adalah penggunaan masker, mencuci tangan menggunakan sabun atau hand sanitizer dan menghindari interaksi langsung dengan orang lain. Selain itu, sterilisasi ruang publik seperti rumah ibadah, sekolah, dan tempat pelayanan umum lainnya dengan penyiraman desinfektan juga diperlukan. Namun, saat ini beberapa produk yang berkaitan dengan pencegahan covid-19 menjadi langka dan bernilai tinggi di pasaran sehingga tidak semua masyarakat atau lembaga dapat memperolehnya. Terlebih, untuk melakukan penyiraman desinfektan pada ruang publik yang luas dibutuhkan cairan desinfektan dan alat pendukung yang sulit didapatkan. Melihat permasalahan tersebut, berbagai kalangan dari berbagai lapisan masyarakat tergerak untuk membantu menyediakan logistik dan memberikan jasa yang dibutuhkan. Beberapa bentuk bantuan jasa yang diberikan diantaranya adalah penyediaan logistik penyemprotan desinfektan, tenaga pelaksana penyemprotan desinfektan serta pembuatan masker dan alat pelindung diri secara gratis. Saat ini, mayoritas gerakan bantuan jasa dilaksanakan secara mandiri kepada penerima bantuan yang mereka temui di sekitarnya. Hal ini dikarenakan para pemberi bantuan menginginkan bantuan yang diberikannya diterima oleh sasaran yang tepat. Kondisi ini menyebabkan tidak meratanya bantuan yang diterima oleh masyarakat. Di sisi lain, di berbagai wilayah masih terdapat potensi penerima bantuan yang lebih membutuhkan. Namun, para pemberi bantuan kesulitan untuk melakukan verifikasi kebenaran permohonan bantuan tersebut.

Peningkatan jumlah kasus positif covid-19 membuat sejumlah fasilitas kesehatan dan lembaga penangan terkait kekurangan tenaga dalam menanganinya. Dalam upaya mempercepat tindakan penanganan covid-19 di Indonesia dibutuhkan relawan yang akan bertugas dalam penanganan medis maupun non medis. Untuk itu, pemerintah melalui gugus tugas covid-19, sejumlah fasilitas kesehatan dan lembaga penanganan covid-19 lainnya telah melakukan perekrutan relawan secara mandiri. Seiring dengan hal tersebut, antusiasme masyarakat untuk dapat membantu semakin meningkat baik dengan mengabdikan diri sebagai relawan dalam penanganan medis maupun non medis. Namun, banyaknya pilihan perekrutan tersebut dapat menimbulkan kebingungan bagi para calon relawan untuk menentukan kemana mereka harus mendaftar dan siapa saja yang membutuhkan jasa mereka. Selain itu, proses verifikasi relawan utamanya untuk kategori medis menjadi penting untuk menentukan keahlian dan posisi penempatannya. Proses perekrutan ini harus dilakukan dalam waktu yang singkat karena tenaga relawan sangat dibutuhkan dalam upaya penanganan kasus covid-19 yang terus meningkat. 
Dengan mempertimbangkan berbagai permasalahan yang telah dijelaskan, dalam masa pandemic covid-19 ini dibutuhkan suatu sistem yang mampu menjadi wadah bagi para pemberi bantuan jasa untuk menyalurkan bantuannya serta wadah bagi masyarakat atau lembaga yang membutuhkan jasa mereka. Informasi yang terdapat dalam sistem seperti daftar penerima bantuan, daftar pemberi bantuan dan perkembangan penyaluran bantuan harus melalui verifikasi untuk menjamin kebenaran informasinya. Untuk itu, dalam penelitian ini diusulkan suatu sistem informasi yang mampu mempertemukan para pemberi bantuan jasa dengan calon penerima bantuan secara terbuka. Sistem ini diharapkan dapat mempercepat proses perekrutan relawan baik medis maupun non medis dan mempercepat upaya pencegahan penyebaran covid-19 di masyarakat.

\section{LANDASAN TEORI}

\section{A. Pencegahan dan Penanganan Coronavirus Disease (Covid-19)}

Coronavirus disease (covid-19) adalah penyakit menular yang disebabkan oleh virus jenis baru yang belum perhan teridentifikasi pada manusia [2]. Covid-19 disebabkan oleh virus corona jenis baru yang sampai saat ini belum ditemukan vaksin pencegahannya. Langkah pencegahan penyebaran covid-19 adalah sebagai berikut [3]:

1. Pencegahan Level Individu

a. Mencuci tangan lebih sering dengan sabun dan air setidaknya 20 detik atau menggunakan hand sanitizer, serta mandi atau mencuci muka jika memungkinkan, sesampainya rumah atau di tempat bekerja, setelah membersihkan kotoran hidung, batuk atau bersin dan ketika makan atau mengantarkan makanan.

b. Hindari menyentuh mata, hidung, dan mulut dengan tangan yang belum dicuci

c. Jangan berjabat tangan

d. Hindari interaksi fisik dekat dengan orang yang memiliki gejala sakit

e. Tutupi mulut saat batuk dan bersin dengan lengan atas dan ketiak atau dengan tisu lalu langsung buang tisu ke tempat sampah dan segera cuci tangan

f. Segera mengganti baju/mandi sesampainya di rumah setelah berpergian

g. Bersihkan dan berikan desinfektan secara berkala pada benda- benda yang sering disentuh dan pada permukaan rumah dan perabot (meja, kursi, dan lain-lain), gagang pintu, dan lain-lain.

2. Pencegahan Level Masyarakat
a. Pembatasan interaksi fisik (Physical contact/physical distancing).
b. Menerapkan etika batuk dan bersin.
c. Karantina kesehatan.
d. Jaga jarak fisik dan pembatasan sosial (Physical and social distancing).

\section{B. Relawan}

Menurut Schroeder (1998) relawan adalah individu yang rela menyumbangkan tenaga atau jasa, kemampuan dan waktunya tanpa mendapatkan upah finansial atau tanpa mengharapkan keuntungan materi dari organisasi pelayanan yang mengorganisasikan suatu kegiatan tertentu secara formal. Selain itu, kegiatan yang dilakukan relawan bersifat sukarela untuk menolong orang lain tanpa adanya harapan akan imbalan eksternal. Ciri-ciri Relawan menurut Omoto \& Snyder (dalam Misgiyanti, 1997), antara lain:

1. Selalu mencari kesempatan untuk membantu.

2. Komitmen diberikan dalam waktu yang relatif lama.

3. Memerlukan personal cost yang tinggi (waktu, tenaga, dan sebagainya).

4. Mereka tidak mengenal orang yang mereka bantu, sehingga orang yang mereka. bantu diatur oleh organisasi dimana mereka aktif didalamnya.

5. Tingkah laku menolong yang dilakukannya bukanlah suatu keharusan. 


\section{Penerima Bantuan Jasa}

Jasa adalah setiap tindakan atau kegiatan yang dapat ditawarkan kepada pihak lain, pada dasarnya tidak berwujud dan tidak mengakibatkan kepemilikan apapun, produksi jasa mungkin berkaitan dengan produk fisik atau sebaliknya [5]. Jasa juga dapat diartikan sebagai sebuah tindakan yang dilakukan untuk membantu seseorang tanpa harus menawarkan bentuk fisik dalam menyelesaikan permasalahannya. Dengan demikian, penerima bantuan jasa dapat diartikan sebagai orang yang menerima manfaat dari tindakan atau kegiatan yang dilakukan oleh pihak lain dalam rangka memberikan solusi dari permasalahan atau meringankan beban yang dihadapinya.

\section{Sistem Informasi}

Sistem informasi adalah suatu kombinasi terartur apapun dari orang, perangkat keras, piranti lunak, jaringan komputer, jaringan komunikasi dan basis data yang mengumpulkan, mengubah dan menyebarkan informasi di dalam suatu bentuk organisasi [6]. Menurut Hanif Al Fatta (2009), keberhasilan suatu sistem informasi yang diukur berdasarkan maksud pembuatanya tergantung pada tiga faktor utama, yaitu : keserasian dan mutu data, pengorganisasian data, dan tatacara penggunaanya.untuk memenuhi permintaan penggunaan tertentu, maka struktur dan cara kerja sistem informasi berbeda-beda bergantung pada macam keperluan atau macam permintaan yang harus dipenuhi. Suatu persamaan yang menonjol ialah suatu sistem informasi menggabungkan berbagai ragam data yang dikumpulkan dari berbagai sumber.

\section{RANCANGAN SOLUSI}

Hasil identifikasi permasalahan yang ada menunjukan bahwa saat ini diperlukan suatu wadah yang mampu mempertemukan para pemberi bantuan jasa dengan mereka yang membutuhkan. System value yang diharapkan dalam sistem informasi bantuan jasa ini adalah sebagai berikut:

- Menjadi wadah bagi volunteer untuk mendaftarkan diri dan mengetahui instansi/lembaga yang membutuhkan bantuan jasa,

- Menjadi wadah bagi instansi/lembaga untuk memperoleh informasi ketersediaan volunteer dan mempercepat proses rekruitmen,

- Menjadi wadah bagi masyarakat/lembaga untuk memperoleh bantuan sterilisasi wilayah,

- Menjadi wadah bagi masyarakat yang ingin berdonasi, dan

- Yang terpenting adalah: menjadi wadah pertemuan antara siapa yang memberi dan siapa yang membutuhkan.

Untuk dapat melakukan pengembangan sistem informasi yang diinginkan, analisis proses bisnis dalam proses perekrutan dan penyaluran bantuan perlu dijabarkan. Dalam sistem informasi bantuan jasa yang diusulkan, terdapat tiga proses bisnis utama yaitu permohonan bantuan, perekrutan pemberi bantuan jasa dan proses penyaluran bantuan.

\section{A. Proses Bisnis Permohonan Bantuan}

Permohonan bantuan adalah salah satu layanan dalam sistem yang bertujuan dalam menampung informasi kebutuhan masyarakat yang membutuhkan bantuan dan belum dapat tertangani. Secara umum, setiap permohonan yang diajukan akan diseleksi melalui tahapan verifikasi oleh verifikator untuk menentukan kebenaran informasi yang diberikan sebelum kemudian diinformasikan kepada calon pemberi bantuan/relawan. 


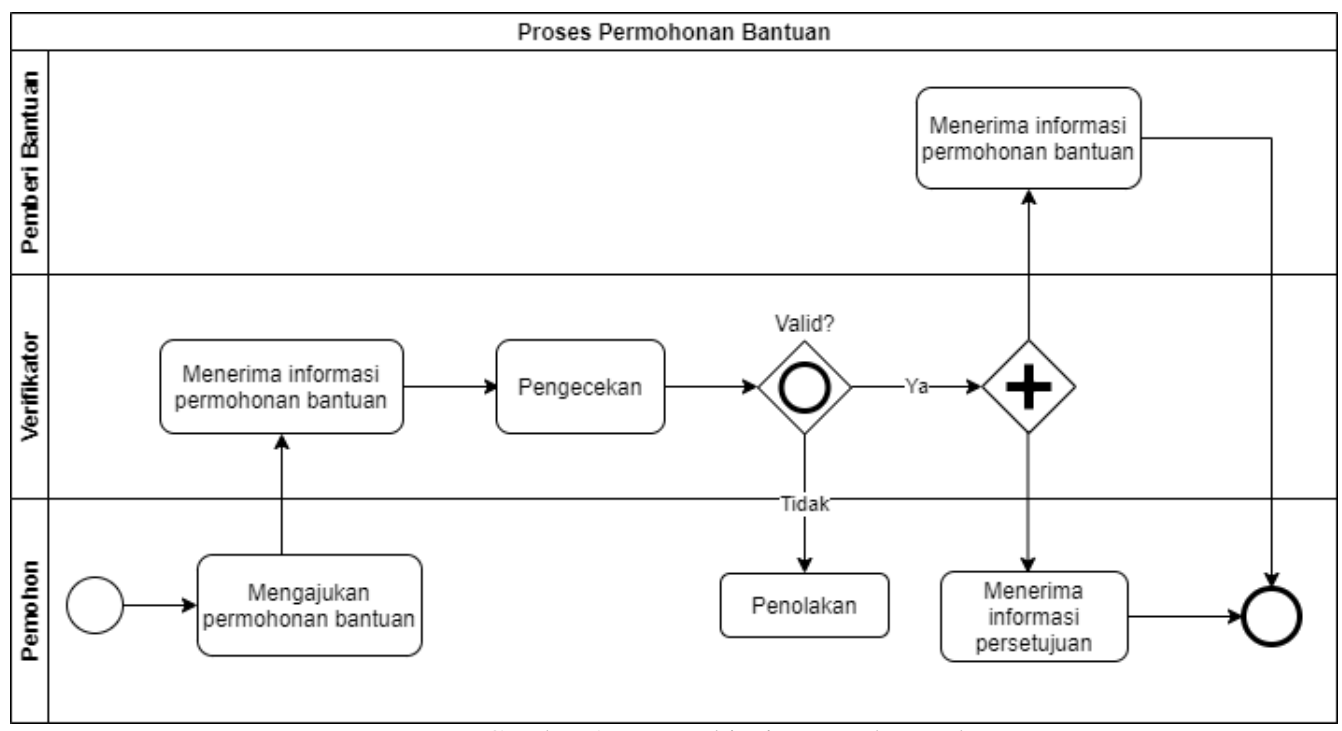

Gambar 2. Proses bisnis permohonan bantuan

\section{B. Proses Bisnis Perekrutan Pemberi Bantuan Jasa}

Perekrutan pemberi bantuan adalah salah satu layanan dalam sistem yang bertujuan dalam menampung relawan medis maupun non medis serta para pemberi bantuan jasa lainnya yang ingin berkontribusi memberikan bantuan. Relawan medis yang mendaftarkan diri harus mampu membuktikan kompetensinya dengan menunjukkan dokumen-dokumen pendukung yang menyatakan kemampuannya dalam bidang medis. Setiap relawan dan pemberi bantuan jasa yang mendaftar harus melalui verifikasi terlebih dahulu untuk dapat melaksanakan kegiatan volunteer.

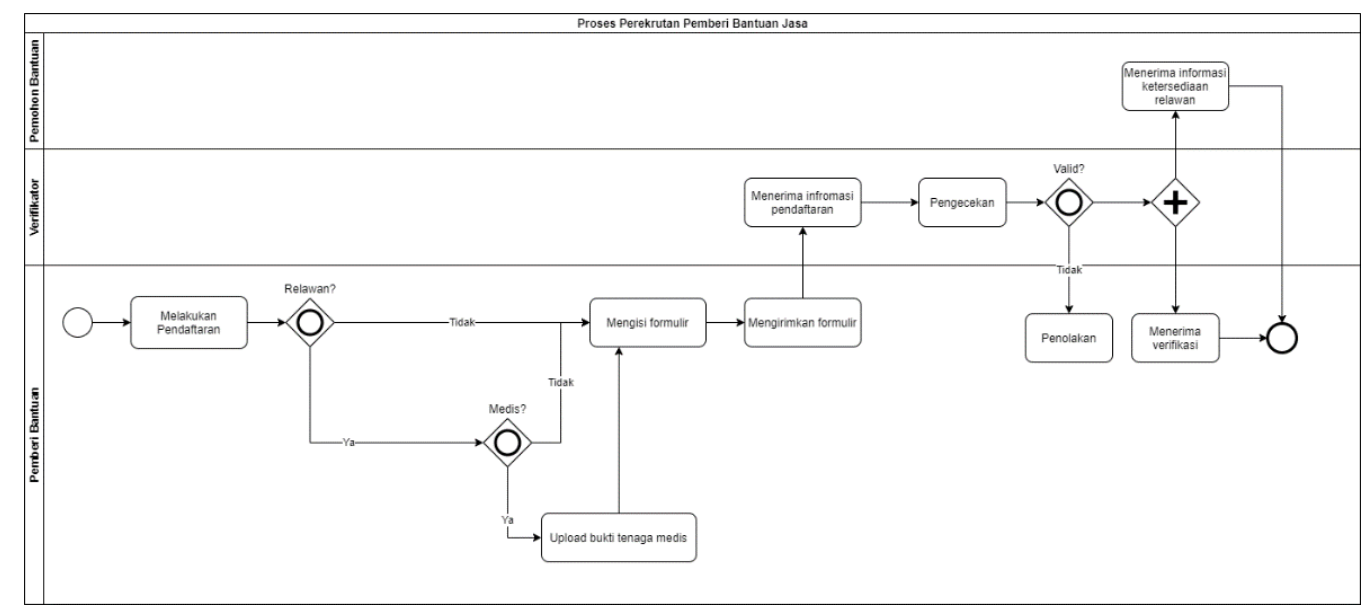

Gambar 3. Proses bisnis perekrutan pemberi bantuan jasa

\section{Proses Bisnis Penyaluran Bantuan Jasa}

Penyaluran bantuan adalah proses bisnis dalam sistem yang menunjukan alur penyaluran bantuan oleh relawan kepada penerima bantuan. Relawan yang terdaftar akan mendapatkan informasi permohonan yang membutuhkan jasanya. Apabila bantuan telah diselesaikan, maka pemberi bantuan/relawan harus memberikan bukti berupa dokumen atau foto yang menyatakan bahwa penyaluran bantuan telah diselesaikan. Penyaluran bantuan akan dinyatakan selesai oleh sistem apabila penerima bantuan/pemohon telah melakukan persetujuan atau tidak ada penolakan oleh pemohon dalam tenggang waktu yang ditentukan. 


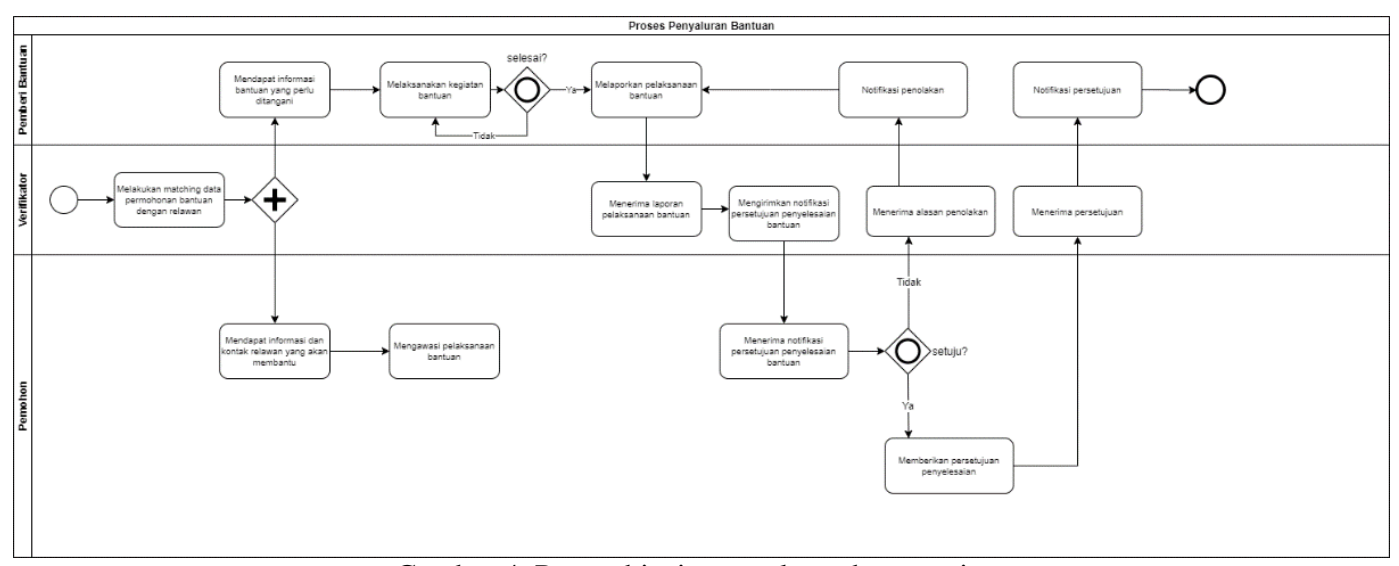

Gambar 4. Proses bisnis penyaluran bantuan jasa

Dengan melakukan analisis pada proses bisnis utama yang ingin dicapai dalam sistem, inovasi layanan teknologi informasi dalam sistem dapat diidentifikasi menjadi empat layanan seperti yang tertera dalam tabel 1 .

Tabel 1. Inovasi layanan teknologi informasi dalam sistem informasi bantuan jasa

\begin{tabular}{|c|l|l|}
\hline No & \multicolumn{1}{|c|}{ Jenis Layanan } & \multicolumn{1}{c|}{ Deskripsi } \\
\hline 1 & $\begin{array}{l}\text { Layanan manajemen } \\
\text { pengguna }\end{array}$ & $\begin{array}{l}\text { Layanan yang dibangun sebagai fitur pengelolaan } \\
\text { pengguna. }\end{array}$ \\
\hline 2 & Layanan pengelolaan bantuan & $\begin{array}{l}\text { Layanan yang dibangun untuk mengelola } \\
\text { permohonan bantuan yang diajukan serta proses } \\
\text { penyalurannya. }\end{array}$ \\
\hline 3 & $\begin{array}{l}\text { Layanan pengelolaan } \\
\text { pemberian bantuan }\end{array}$ & $\begin{array}{l}\text { Layanan yang dibangun sebagai fitur dalam } \\
\text { mengelola perekrutan pemberi jasa dan relawan. }\end{array}$ \\
\hline 4 & Layanan verifikasi data & $\begin{array}{l}\text { Layanan yang dibangun untuk verifikator/admin } \\
\text { dalam melakukan verifikasi terkait permohonan } \\
\text { bantuan, perekrutan relawan serta proses } \\
\text { penyaluran bantuan jasa. }\end{array}$ \\
\hline
\end{tabular}

Rancangan arsitektur keseluruhan sistem informasi bantuan jasa yang akan dibangun dapat dilihat pada gambar 5. Sistem informasi dirancang dalam empat layer yaitu resources, model and composition layer, application layer, dan system user. Sistem akan diimplementasikan dalam bentuk website dengan berbagai fitur pendukung untuk kemudian dapat dimanfaatkan oleh pengguna yang terdiri dari verifikator/ admin dan masyarakat yang dapat berlaku sebagai pemohon maupun pemberi bantuan jasa. 


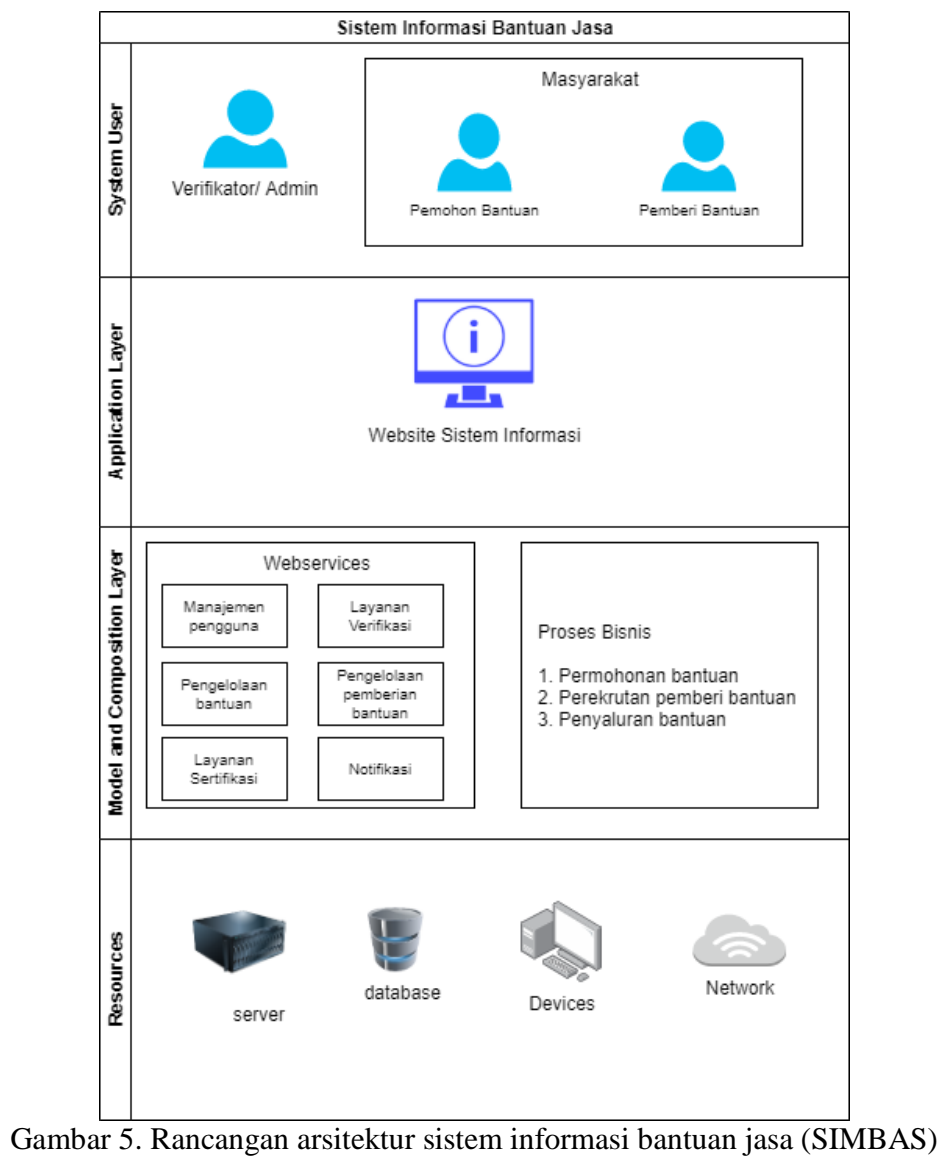

\section{PENGEMBANGAN SISTEM}

Pengembangan sistem informasi bantuan jasa (SIMBAS) dilakukan berdasarkan hasil rancangan sistem yang telah dibuat. Skenario keseluruhan sistem (gambar 6) yang berjalan dapat dijabarkan sebagai berikut:

1. Pengguna menuju alamat website melalui web browser untuk membuka halaman depan SIMBAS.

2. Pengguna dapat melihat informasi terkait perkembangan covid-19 dan penggunaan sistem pada halaman depan.

3. Untuk melakukan pendaftaran pemberi jasa maupun membuat permohonan bantuan, pengguna yang belum memiliki akun diharuskan mendaftar terlebih dahulu dengan fitur sign up. Pengguna yang telah terdaftar dapat masuk ke halaman utama dengan menu login.

4. Pengguna dapat membuat permohonan bantuan dengan menggunakan fitur yang disediakan. Permohonan bantuan baru akan ditawarkan pada para pemberi bantuan jasa apabila lolos verifikasi oleh admin/ verifikator.

5. Pengguna dapat mendaftarkan diri sebagai pemberi bantuan jasa atau relawan dengan mengisi formulir yang disediakan dan melampirkan beberapa dokumen pendukung untuk posisi relawan tertentu. Posisi pemberi bantuan atau relawan baru akan disetujui apabila telah lolos verifikasi oleh admin/ verifikator.

6. Proses alokasi penyaluran bantuan dilakukan oleh admin/ verifikator dengan mengacu pada ketersediaan pemberi bantuan jasa atau relawan dengan jenis bantuan jasa yang diinginkan pemohon.

7. Proses penyaluran bantuan akan dinyatakan selesai apabila pemberi bantuan jasa atau relawan telah melakukan unggah dokumen bukti penyelesaian yang kemudian disetujui oleh penerima bantuan atau tidak ada penolakan oleh penerima bantuan dalam tenggang waktu tertentu. 


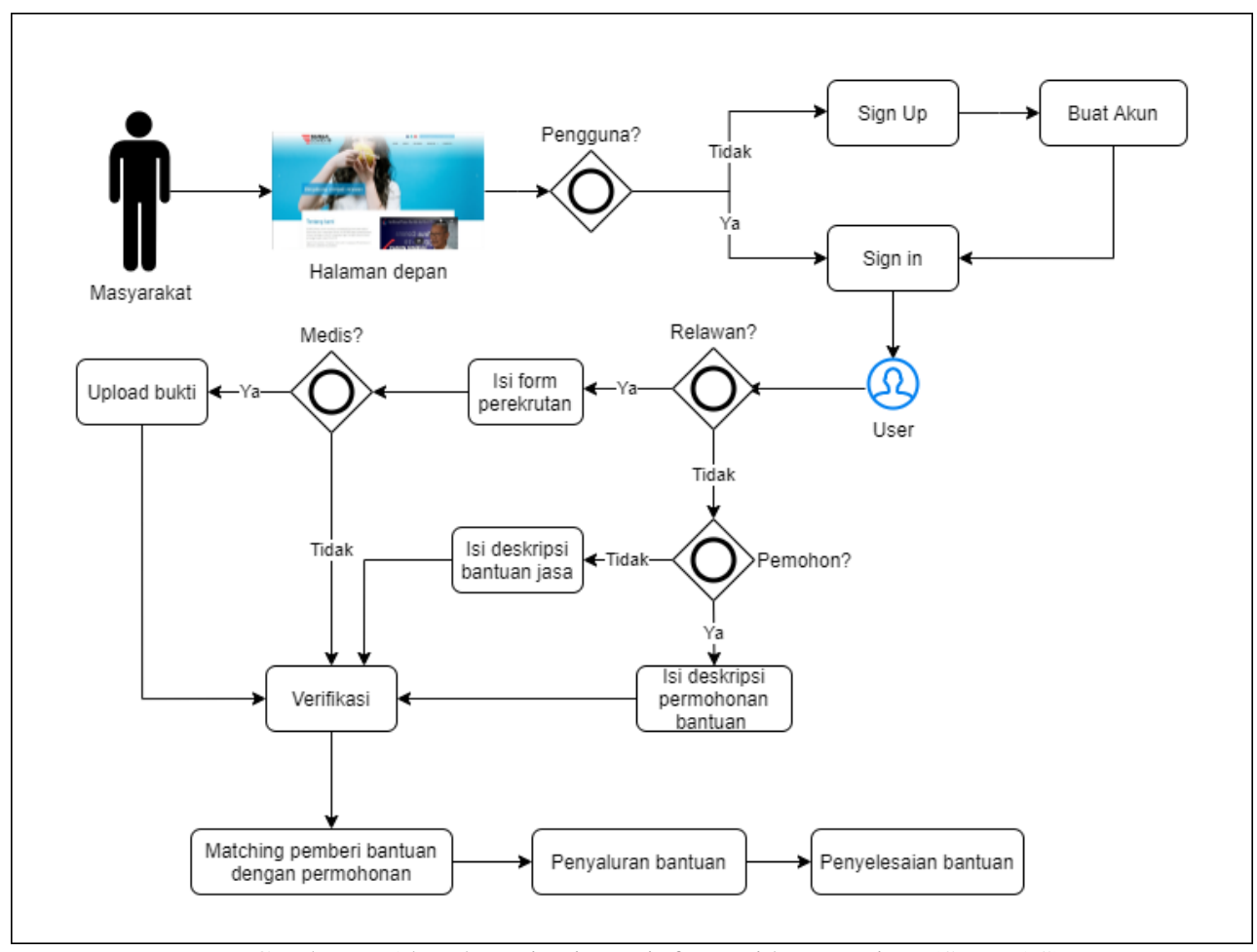

Gambar 6. Alur skenario sistem informasi bantuan jasa (SIMBAS)

Hasil implementasi rancangan dan skenario sistem informasi bantuan jasa dapat dilihat pada gambar 7, 8 dan 9. Gambar 7 merupakan tampilan halaman depan website, gambar 8 adalah tampilan informasi terkait covid-19 sedangkan gambar 9 merupakan tampilan menu-menu yang digunakan dalam proses permohonan bantuan dan perekrutan pemberi bantuan atau relawan.

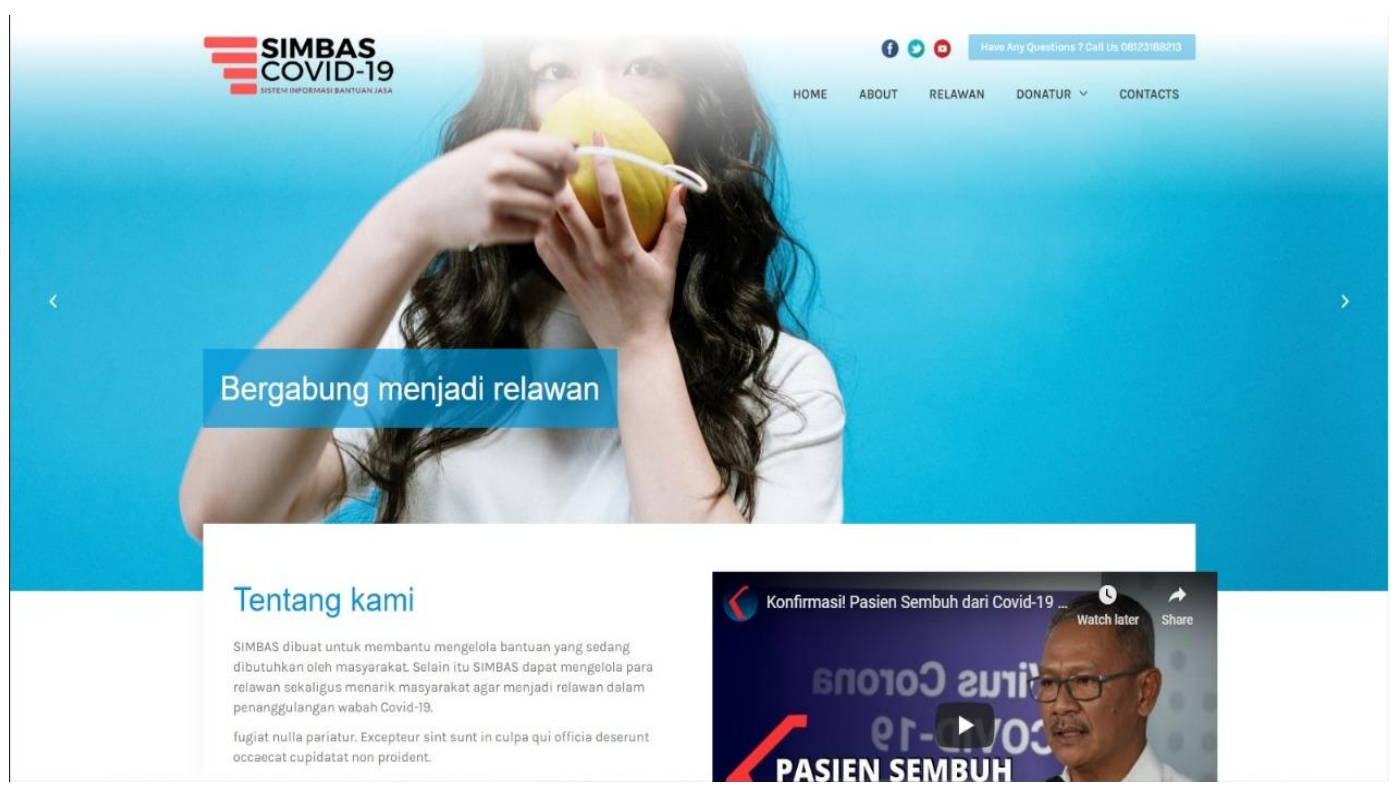

Gambar 7. Tampilan halaman depan sistem informasi bantuan jasa (SIMBAS) 


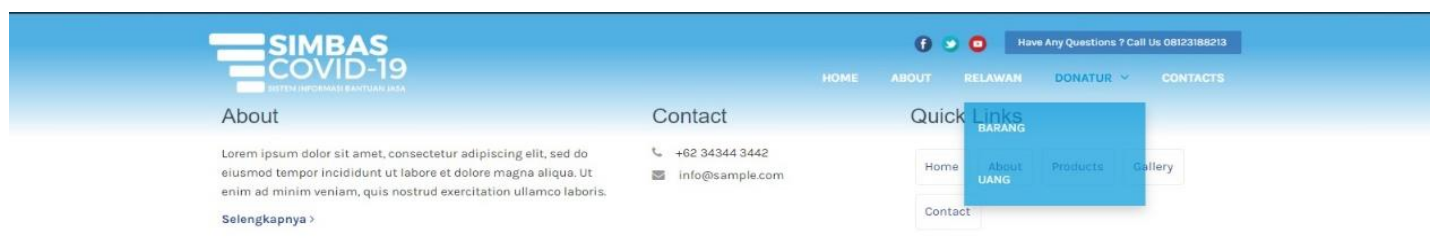

\section{Get In Touch}

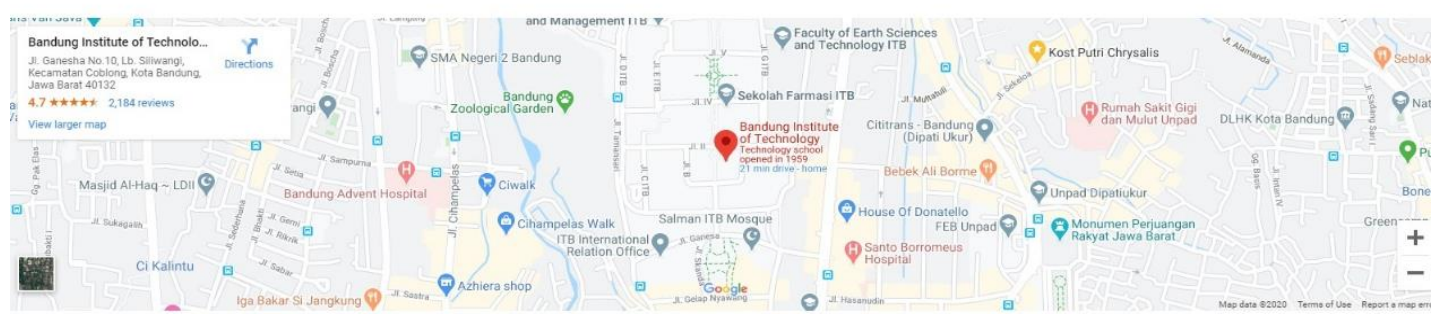

Gambar 8. Tampilan halaman informasi sistem informasi bantuan jasa (SIMBAS)

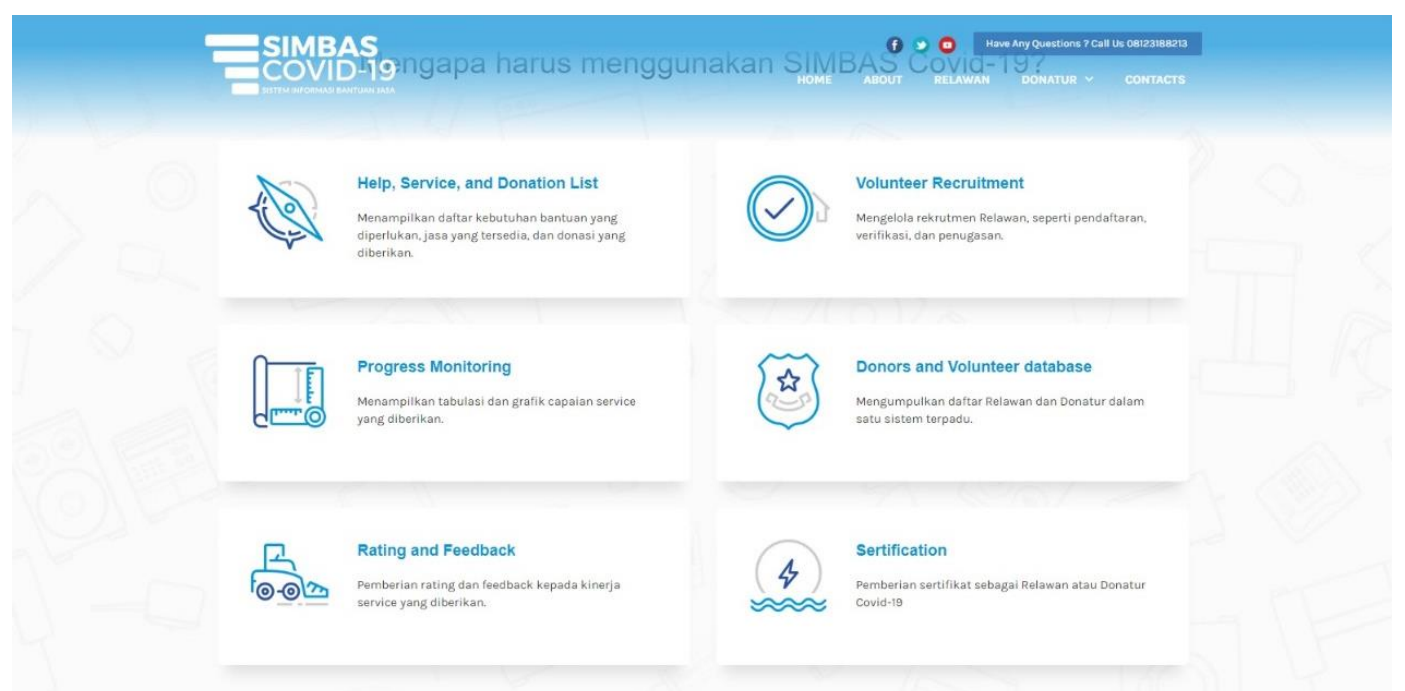

Gambar 8. Tampilan halaman menu utama sistem informasi bantuan jasa (SIMBAS)

\section{KESIMPULAN DAN SARAN}

Sistem informasi bantuan jasa (SIMBAS) merupakan suatu sistem yang mampu menghubungkan para calon penerima bantuan jasa dan relawan kepada para calon penerima bantuan yang membutuhkan melalui sebuah sistem yang terbuka dan mudah diakses. SIMBAS dapat mempermudah dan mempercepat proses perekrutan relawan pada fasilitas kesehatan dan lembaga penanganan covid19. Keterbukaan sistem informasi yang disediakan membuat para pemberi bantuan jasa dengan mudah dapat menemukan para penerima bantuan yang membutuhkan. Keberadaan sistem informasi ini berpotensi mengurangi jumlah kebutuhan akan bantuan jasa yang tidak tertangani di berbagai wilayah. Dalam penelitian lanjutan, proses verifikasi dalam sistem masih menjadi isu yang dapat dikembangkan. Verifikasi yang dimaksud antara lain menentukan mekanisme yang tepat untuk menilai kredibilitas calon pemberi bantuan dan meyakinkan kebenaran informasi serta tingkat urgensi permohonan bantuan yang diajukan. 


\section{DAFTAR PUSTAKA}

[1] Gugus Tugas Penanganan Covid-19, Infografis COVID-19 (1 Mei 2020), 1 Mei 2020. [Online]. Available at: https://covid19.go.id/p/berita/infografis-covid-19-1-mei-2020.

[2] WHO, Coronavirus overview. [Online]. Available at: https://www.who.int/healthtopics/coronavirus\#tab=tab_1.

[3] Gugus Tugas Penanganan Covid-19, Pedoman Penanganan Cepat Medis Dan Kesehatan Masyarakat COVID-19 di Indonesia, Jakarta, Gugus Tugas Covid-19, 2020.

[4] R. Rini, B. Wibhawa, M. Santoso, dan R. Santoso, "Pentingnya buku panduan bagi volunteer pada organisasi sosial (studi kasus pada lembaga rehabilitasi odha dan konsumen napza rumah cemara kota bandung)", Social Work Journal, vol. 7, 2017.

[5] R. Lupiyadi dan A. Hamdani, Manajemen Pemasaran Jasa, Jakarta, Salemba Empat, 2006.

[6] O’Brein and James A., Pengantar Sistem Informasi, Jakarta, Salemba 4, 2005.

[7] L. Zhang, J. Zhang, dan H. Cai, Services Computing. New York: Springer US, 2007.

[8] Suhardi, N. B. Kurniawan, J. Sembiring, dan P. Yustianto, "Service Systems Engineering Framework Based on Combining Service Engineering and Systems Engineering Methodologies," in International Conference on Information Technology and System Innovation, 2017. 